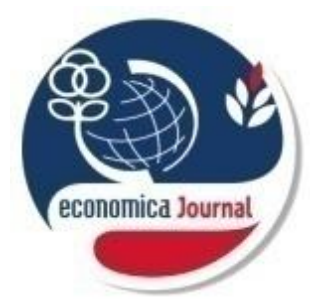

ISSN : $2302-1590$

E-ISSN: $2460-190 X$

\title{
ECONOMICA
}

Jurnal Program Studi Pendidikan Ekonomi

STKIP PGRI Sumatera Barat Vol.9 No.1 (1 - 6)

\section{CRITICAL THINKING ACCOUNTING STUDENTS USING PROBLEM BASED LEARNING INTEGRATING WITH ICT MEDIA}

\author{
By \\ Betanika Nila Nirbita ${ }^{1)}$, Soetarno Joyoatmojo ${ }^{2)}$ \\ ${ }^{1)}$ Faculty of Teacher Training and Education, Siliwangi University Indonesia \\ Email: betanika@unsil.ac.id \\ ${ }^{2)}$ Faculty of Teacher Training and Education, Sebelas Maret University Indonesia \\ Email: strn_jo@yahoo.co.id \\ Submitted: 2020.02.06 Reviewed: 2020.04.04 Accepted:2020.10.23 \\ https://doi.org/10.22202/economica.2020.v9.i1.3935
}

\begin{abstract}
Critical thinking ability is one skill that students must behave so students get used to analyzing and solving the problem in the world of work, especially the world of accounting. A lot of students don't have critical thinking abilities. This study aims to determine the improvement of students' critical thinking skills by using problem based learning model integrating ICT media. The sampling technique used cluster random sampling in Boyolali, Indonesia. This research uses an action research approach. Data collection in this research using observation techniques, interviews, and documentation. This research uses interviews, observation sheets, tests, and documentation as research analysis tools. This research uses 2 cycles with 72 students in class X Accounting SMK Negeri 1 Boyolali. The validity of the data used triangulation of sources, data, and methods. The result of this research by using problem based learning model with ICT media shows that there is an increase of critical thinking ability of accounting students which consists of five aspects of critical thinking that are aspects of the ability to formulate questions, give the argument, collect and arrange information, analyze the problem, and decision making and making a conclusion
\end{abstract}

Jel Classification:

A2; $121 ;$ L82

Keywords: Problem Based Learning; ICT; Critical Thinking

C2020 Prodi Pendidikan Ekonomi STKIP PGRI, Padang 


\section{INTRODUCTION}

The ongoing ASEAN Free Trade Area (AFTA) Agreement is one part of the globalization era that has an impact on intense competition. The competition not only covers competition in terms of trade and industry but also the competition of human quality. One of the perceived impacts of AFTA is the arrival of foreign workers who can enter the ASEAN country environment freely so that the competition between individuals in every competence in obtaining work tends to be more difficult. Based on the above, the improvement of ability and competence of human in Indonesia becomes a very important thing

The enforcement of AFTA in the era of globalization as described becomes a big challenge for Vocational High School graduates (SMK). The increasingly fierce competition requires SMK to always improve the quality of graduates that ultimately the graduates can compete in the world of work. One of the influences to produce the quality of competent graduates is success in the learning process. Learning at the secondary school level, between high school (SMA) and vocational high school (SMK) has a difference. The learning process in vocational high schools focuses on the mastery of knowledge, skills, attitudes, and values that will be needed in the industry. Learning in SMK uses more practice than just rote or lecture in the classroom. The activity aims to enable students to master each competency and one of their competencies is to apply to the competency standard of graduates (SKL) in the vocational high school education unit by showing the ability of logical thinking, creative thinking, innovative and critical thinking in every decision making (Permendiknas No 23, 2006). Accordingly, learning in vocational high schools needs more attention. The results of Banfield \& Kay (2008) analyze the development that will occur in the $21 \mathrm{st}$ century and identify 5 new conditions in life that each requires a certain competence. These conditions include (1) global competition with global awareness and independence, (2) global cooperation which means cooperation, ability to cooperate, and ability to master ICT (Information, Communication, and Technology), (3) growth of information they need for technologically literate people, critical thinking and problem solving (4) work and career development that requires critical thinking, problem-solving, innovation, flexibility, and can easily adapt, (5) knowledge-based economic development which requires people of information literacy, critical thinking and problemsolving. Based on these 5 conditions, information literacy, critical thinking, and problem-solving are important skills that must be owned by students.

Critical thinking is not the same as accumulating information. A person with good memory and many facts does not mean a critical thinker, Eggen, and Kauchak (2012, p.112). A critical thinker can deduce from what he knows and knows how to use the information to solve problems and search for sources of information relevant to him, Eggen and Kauchak (2012, p.112). The ability to think critically in learners will help when learners will face the internship or enter the business world, Eggen and Kauchak (2012, p.111). Bierstaker, Bedard, and Biggs (2015, p.32) also advise educators or teachers to improve students' critical thinking skills as part of the student's educational implications of accounting, since accounting requires more critical thinking skills in decision making. That's skill is required when students have entered the business world/industries.

Based on the results of interviews with accounting teachers, teachers still tend to use conventional media that have not been able to stimulate students to think critically that 
resulted in low student value. UNESCO explained that the state of Indonesia is ranked 69 out of 76 countries in the field of education. This must be addressed and to build critical thinking skills, teachers can design the learning process. Teachers design learning by giving problems that involve students' critical thinking skills and involve the process of analyzing based on actual problems. One of the learning models that can be applied is a problem based learning model. statement Chen, Lin, and Chang (2011, p.518) which explains that Problem Based Learning refers to a learning approach that focuses on the problem-solving process by learners in obtaining the necessary knowledge. Eggen and Kauchak (2012, p.307) state that problem-based learning is a set of teaching models that use problems as a focus for developing problem-solving skills, materials, and self-organization. Problem Based Learning has the most powerful teaching methods to invite learners in applying a responsibility to learners in learning (Chakravarthi and Vijayan, 2010, p.39).

Problem based learning is an active learning model using real-world problems and learners are required to find solutions to the problems they face and this is an effective learning strategy, Tan and Frank (2006, p.426). To support problem based learning, then used media that can improve students' critical thinking ability. The media used to support this PBL learning model should also be able to cultivate critical thinking skills in learners. This is supported by research from Chen and Chen (2010, p.25) who said that to support the learning of PBL then it takes digital media to make learning better. Media is used to clarify the message to be conveyed, raises the passion and enthusiasm of learners so that learners can follow the course of learning, and also facilitate learners in accepting the delivered lessons. Ebner and Holzinger (2007, p.887), said that learning by not using the media as a learning tool, will have an impact on learning and learners, that learning will feel more severe in the process of delivery and the ability to think critically learners will tend to decrease. the difference in this study is the use of ICT media to help model problem-based learning to improve students' critical thinking skills on basic banking subjects by using video-based problems incorporated in an ICT application. Supporting our knowledge, this research approach has not been reported.

The difference of this research with others research is the use of Problem Based Learning models with ICT media which consists of problem-based video and PowerPoint using five indicators of critical thinking skills, that are aspects of the ability to formulate questions, give an argument, collect and arrange information, analyze a problem, and decision making and making a conclusion. This study aims to determine the improvement of students' critical thinking skills by using problem based learning model integrating ICT media.

\section{METHODS}

This research used an action research approach with a two-cycle. Every action to increase critical ability is designed into one cycle consisting of four stages, namely: (1) Planning; (2) Acting; (3) Observing; and (4) Reflecting for the next planning cycle. Sources of data used in this study are interviews with informants, places or locations, events, documents or archives, and documentation. This research uses interviews, observation sheets, tests, and documentation as research analysis tools. Informants in this study are basic banking subjects and students of class X Accounting SMK Negeri 1 Boyolali consist of 72 students. Documents or archives used are students' daily test scores and student observation data. Data collection techniques used are observation, interview, test, and 
documentation. Test the validity of the data using source or method triangulation and content validity. Data analysis using qualitative and quantitative data. In one cycle the research procedure consists of action planning, action implementation, observation, and reflection.

\section{RESULTS AND DISCUSSION}

Data on students' critical thinking ability is obtained by using the observation sheet of critical thinking ability which consists of five aspects, they are aspects of the ability to formulate questions, give arguments, collect and compile information, analyze problems, and make decisions and make conclusions. Students' critical thinking skills are measured on basic banking subjects to prepare students for internships in the world of banking so that students are able and accustomed to critical thinking. Before the research, the observation sheets to be used will be based on predetermined indicators with $75 \%$ success criteria. The appraisal sheet is consulted to the expert for the views of the indicator and the observation sheet. Observations were made by 4 observers who were tasked with observing the behavior and actions of students in the classroom to measure students' critical thinking skills. The data obtained showed that students' critical thinking ability using problem based learning method using ICT media increased from precycle, first cycle, and the second cycle. This can be seen in the table below:

Table 1. Improvements of Students Critical Thinking Ability SMK Negeri 1 Boyolali

\begin{tabular}{|c|c|c|c|c|c|c|}
\hline \multirow{3}{*}{ Indicator } & \multicolumn{6}{|c|}{ Critical Thinking } \\
\hline & \multicolumn{2}{|c|}{ Pre cycle } & \multicolumn{2}{|c|}{ cycle I } & \multicolumn{2}{|c|}{ cycle II } \\
\hline & Have & No & Have & No & Have & No \\
\hline Ability to conduct questions & 31 & 40 & 52 & 19 & 64 & 7 \\
\hline Ability to give argumentations & 35 & 36 & 49 & 22 & 63 & 8 \\
\hline $\begin{array}{l}\text { Ability to collect and composing } \\
\text { informations }\end{array}$ & 49 & 22 & 54 & 17 & 66 & 5 \\
\hline Ability to analyze problems & 29 & 42 & 44 & 27 & 61 & 10 \\
\hline $\begin{array}{l}\text { Ability to make decisions and } \\
\text { conclusions }\end{array}$ & 27 & 44 & 46 & 25 & 59 & 8 \\
\hline
\end{tabular}

(Source: Processed Primary Data, 2018)

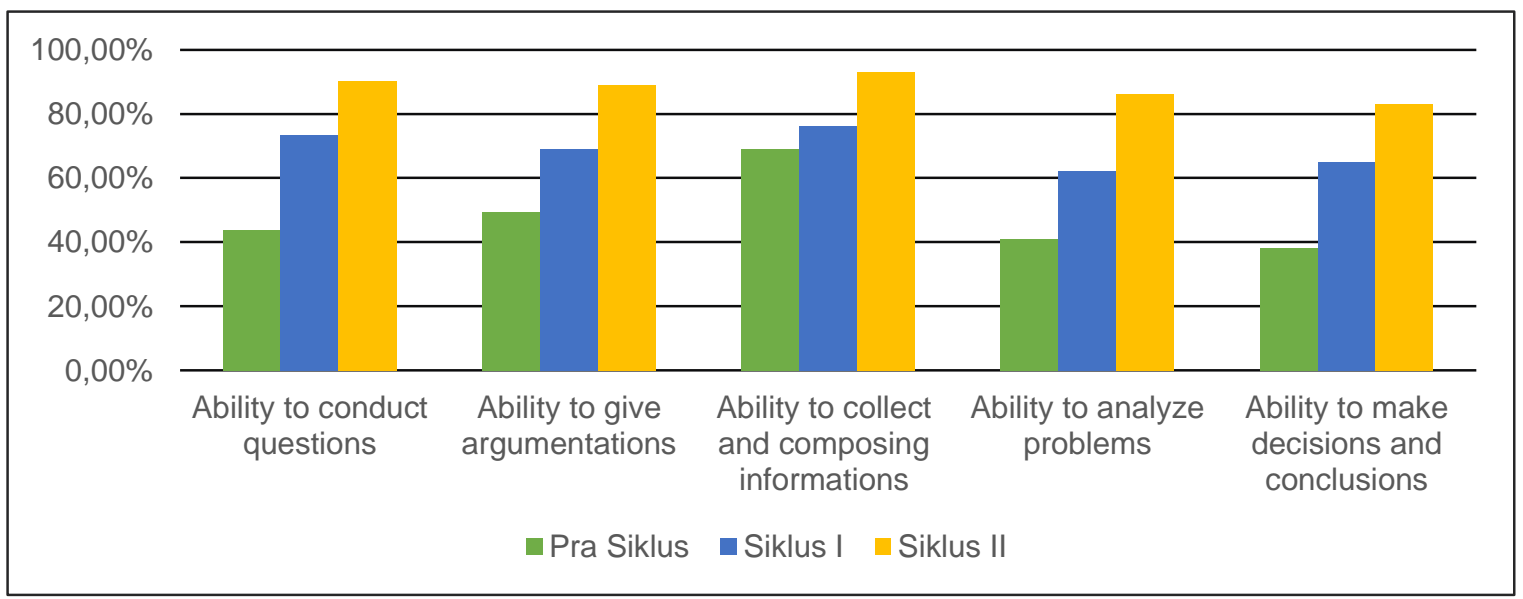

Figure 1. Percentage of Improvements of Students Critical Thinking Ability SMK Negeri 1 Boyolali 
Based on the above data, it can be seen that the percentage of achievement targets ( $75 \%$ ) can be achieved. The students' critical thinking ability is measured by using five aspects such as aspects of the ability to formulate questions, give arguments, collect and compile information, analyze problems, and make decisions and make conclusions in cycle I and cycle II experience change and improvement. Aspects of the ability to formulate questions before the action $43.66 \%$ increased by 29.58 to $73.24 \%$ in the first cycle and increased to $90.14 \%$ in cycle II, which means an increase of $16.9 \%$. Ability to give argument before done action equal to $49,30 \%$ change $19,71 \%$ to $69,01 \%$ and experiencing improvement in cycle II become $88,73 \%$. Aspects of the ability to collect and arrange the information on cycle I increased $7.05 \%$ (before action $69,01 \%$ and cycle I 76,06\%). In cycle II also experienced an increase of $16.90 \%$ ( $76.06 \%$ of the cycle I and cycle II 92.96\%). The fourth aspect is the ability to analyze the problems in the first cycle has a change of $21.11 \%$ (before action $40.86 \%$ and cycle I $61.97 \%$ ), in cycle II also increased by $23.95 \%$ (cycle I $61.97 \%$ and cycle II $85.92 \%)$. The fifth aspect of decision-making ability and making conclusion change in cycle I am $26,76 \%$ (before action 38,03\% and cycle I 64,79\%), in cycle II, also change $18,31 \%$ (cycle I 64 , $79 \%$ and cycle II $83.10 \%$ ).

Based on the implementation of the action in cycle I and cycle II it can be seen that there is an increase in the critical thinking skills of accounting students by using Problem based learning models using ICT media. The result of the improvement of critical thinking ability which consists of five aspects is using a problem based learning model using ICT media. Each cycle consists of three meetings. The first meeting of the teacher explains the learning that will be implemented and provide learning objectives to learners. Master then divides the group by using a puzzle game. Students search for their partners by matching the puzzle they get. One group consists of 6 students. Teachers provide ICT media to students to be viewed on the computers of each group. The teacher invites students to view the problem video on the savings material and the students analyze the problem. Students seek answers using existing media and from other sources such as books or the internet. At the first meeting, students make a presentation in the form of answers to the problems they get that will then be presented in front of the class. At the second meeting proceed with the group presentation and continued to add material to be submitted by the teacher and conclude about the learning that has been done. The third meeting conducted tests to determine student learning outcomes. In all three meetings, observers observed student behavior and assessed using the observation sheets of students' critical thinking skills. Percentage of achievement targets in the first cycle there are still aspects that have not met the target achievement (75\%). Therefore it is held cycle II with some revisions, one of them to attract students to further improve their critical thinking skills, teachers give rewards to students.

Eggen and Kauchak (2012, p.307) state that problem-based learning is a set of teaching models that use problems as a focus for developing problem-solving skills, materials, and self-organization. Problembased learning has the most powerful teaching methods to invite learners in applying a responsibility in learning (Chakravarthi and Vijayan, 2010, p.39). Learning Problem-based learning is an active learning model using real-world problems and learners are required to find solutions to the problems they face and this is an effective learning strategy, Tan and Frank (2006, p426). Problems taken can be given in the 
form of video problems that are included in the scope of Information, Communication, and Technology). Buckingham (2003, p.97) states that the use of ICT media will make learners more critical in the submission of questions. The use of a problem based learning model by using ICT learning media can improve students' thinking ability. Chen and Chen (2010, p.7) revealed that the problem-based learning model if used with the help of ICT will facilitate teachers and learners as well as learning processes that occur in the classroom. Barrows (2002, p.119) says that the Problem Based Learning model can help learners develop the ability to solve problems, critical thinking, and selflearning while gaining knowledge in the various subject areas of learning.

\section{CONCLUSION}

Based on the results of data analysis it can be concluded that the implementation of the Problem Based Learning model by using ICT media can improve the critical thinking ability of students of SMK Negeri 1 Boyolali. Improvement of students' critical thinking skills consists of five aspects: the ability to formulate questions, give arguments, collect and organize information, analyze problems, and make decisions and make conclusions. Based on the above, the problem-based learning model using ICT media should be used by teachers at the time of learning to produce students with critical thinking skills of high students. Other research may be researching the development of students' critical thinking skills by using problem based learning model with ICT media

\section{REFERENCE}

Banfield, P., \& Kay, R (2008). Pengantar Manajemen Sumber Daya Manusia (1st ed.). Oxford: Oxford University Press. ISBN 978-0-19-929152-6 .
Barrows, H. (2002). Is it possible to have such a thing as PBL?. Distance Education, 23(1), 119-122.

Bierstaker, J.L., Bedard, J.C. \& Biggs, S.F. (2015). Fostering critical thinking in accounting education. Advances in Accounting Education Teaching and Curriculum Innovations, 2 (1), 21-36.

Buckingham, D. (2003). Media Education. Cambridge: Polity Press

Chakravarthi, S. \& Vijayan, P. (2010). Analysis of the psychological impact of problem based learning (PBL) toward self-directed learning among students in undergraduate medical education. International Journal of Psychological Studies, 2 (1), 38-43

Chen, C.M. \& Chen, C.C. (2010). Problembased learning supported by digital archives: a case study of Taiwan libraries' history digital library. The Electronic Library, 28 (1), 5-28

Chen, K.N., Lin, P.C. \& Chang, S.S. (2011). Integrating library instruction into a problem-based learning curriculum. Aslib Proceedings, 63 (5), 517-532.

Ebner, M. \& Holzinger, A. (2007). Successful implementation of user centered game based learning in higher education: An example from civil engineering. Computer and Education Journal, 49, 873-890.

Eggen, P \& Kauchak, D. (2012). Strategi dan Model Pembelajaran. Jakarta: PT. Indeks

Kementerian Pendidikan dan Kebudayaan Republik Indonesia. Peringkat dan capaian PISA mengalami peningkatan. https://www.kemdikbud.go.id/main/bl og/2016/12/peringkat-dan-capaianpisa-indonesia-mengalamipeningkatan. 
Permendiknas. (2006). Peraturan Menteri Pendidikan Nasional No 23 Tahun 2006 tentang Tujuan PendidikanTan, S.S. \& Frank, C.K. (2006). A problem - based learning approach to entrepreneurship education. Education and Training Journal, 48 (6), 416-428. 